\title{
Olive oil as an alternative to boar semen cryopreservation ${ }^{\not}$
}

\section{Aceite de oliva como una alternativa para la criopreservación de semen suino}

\section{O azeite de oliva como uma alternativa para a criopreservação do sêmen suíno}

Estela Ferandes e Silva ${ }^{1 *}$, Biotecnol, MsC; Tainã Figueiredo Cardoso ${ }^{1}$, Biotecnol., MsC; Fabiana Lemos Goulart Dutra², Nutric., Dr.; Antonio Sergio Varela Junior'1, MV, Dr.; Fábio Pereira Leivas Leite², MV, PhD; Carine Dahl Corcini², MV, Dr.

*Corresponding author: Estela Fernandes e Silva, Universidade Federal do Rio Grande - Campus Carreiros, Av. Itália km 8 Bairro Carreiros 475 - Aeroporto, Rio Grande - E-mail: starfs@hotmail.com, zip code: 96203-900.

${ }^{1}$ Universidade Federal do Rio Grande - FURG, Rio Grande, RS, Brasil

${ }^{2}$ Universidade Federal de Pelotas - UFPel, Pelotas, RS, Brasil

(Recibido: 4 de noviembre, 2015; aceptado: 3 de marzo, 2016)

\begin{abstract}
The aim of this study was to evaluate different concentrations of olive oil for cryopreservation of boar semen. A total of 21 eyaculates of 18 males with motility $\geq 70 \%$ were used. For freezing, the semen was diluted in treatments: control (Cont-egg yolk), "Koroneiki" oil in egg yolk at 0.25\% (A025), 0.50\% (A050), 0.75\% (A075) and 1.0\% (A10). Straws with $5.10^{7} \mathrm{sperm} / \mathrm{ml}$ were frozen and stored in liquid nitrogen. Thawing was done at $37^{\circ} \mathrm{C}$ for 30 seconds and motility, mitochondrial functionality, DNA integrity, oocite penetration rate and the number of sperm per oocite (in the in vitro penetration trial) were evaluated. The variables were compared using the Kruskal-Wallis test. Even though no statistical difference was found between control and treatments containingolive oil ( $\mathrm{p}>0.05)$, the treatment with $0.25 \%$ oil concentration showed tendences towards sperm protection, outperforming the controls in mitochondrial functionality and preservation of the fertilizing capabilities in the in vitro penetration trial. This is why, olive oil could represent an alternative to help cryopreservation of boar semen.
\end{abstract}

\section{Key words}

Antioxidants, in vitro penetration trial, mitochondrial functionality.

\section{Resumen}

El objetivo de este estudio fue evaluar diferentes concentraciones de aceite de oliva para la criopreservación de semen de verraco. Se utilizaron 21 eyaculados de 18 machos con motilidad igual o superior al 70\%. Para la congelación, el semen se diluyó en los tratamientos: control (Cont) (lactosa yema), 0,25\% (A025); 0,50\% (A050); 0,75\% (A075) y $1,0 \%$ (A10) de aceite de la variedad "Koroneiki" en lactosa yema. Pajas con $5.10^{7}$ espermatozoides / ml, fueron congeladas y almacenadas en nitrógeno líquido. La descongelación se produjo a $37^{\circ} \mathrm{C}$ durante 30 segundos y se evaluó: la motilidad, la funcionalidad de la mitocondria, la integridad del ADN, la tasa de penetración de ovocitos y el número de espermatozoides por ovocito (en el ensayo de penetración in vitro). Las variables se compararon mediante la prueba de Kruskal-Wallis. Aunque no hubo diferencia estadística entre el control y los tratamientos

${ }^{\square}$ To cite this article: Ferandes e Silva E, Figueiredo Cardoso T, Lemos Goulart Dutra F, Varela Junior AS, Pereira Leivas Leite F, Dahl Corcini C. Olive oil as an alternative to boar semen cryopreservation. Rev. CES Med. Zootec. 2016; Vol 11 (1): 8-14. 
que contienen aceite de oliva ( $p>0,05)$, la concentración de $0,25 \%$ de este aceite mostró tendencias de protección de esperma, superando el control en la funcionalidad de las mitocondrias y en la preservación de la capacidad fertilizante en el ensayo de penetración in vitro. Por lo tanto, el aceite de oliva puede representar una alternativa para ayudar en la criopreservación de semen porcino.

\section{Palabras clave}

Antioxidantes, ensayo de penetración in vitro, funcionalidad de la mitocondria.

\section{Resumo}

O objetivo de este estudo foi avaliar diferentes concentrações de azeite de oliva para a criopreservação de sêmen suíno. Utilizaram-se 21 ejaculados de 18 machos com motilidade igual ou superior ao 70\%. Para o congelamento, o sêmen se dilui-o nos tratamentos: controle (Cont) (lactose-gema), 0,25\% (A025); 0,50\% (A050); 0,75\% (A075) e $1,0 \%$ (A10) de azeite da variedade "Koroneiki" em lactose-gema. Palhetas com uma dose de 5.107 espermatozoides/ $\mathrm{ml}$ foram congeladas e armazenadas em nitrogênio liquido. $\mathrm{O}$ descongelamento se produz a $37^{\circ} \mathrm{C}$ durante 30 segundos e se avaliaram: motilidade, funcionalidade da mitocôndria, integridade do DNA, taxa de penetração de ovócitos e o número de espermatozoides por ovócito (no teste de penetração in vitro). As variáveis se compararam mediante o teste de Kruskal-Wallis. Ainda que não houve diferença estatística entre o controle e os tratamentos que continham azeite de oliva $(\mathrm{p}>0,05)$, a concentração de $0,25 \%$ de azeite de oliva teve tendências de proteção do esperma, superando o controle na funcionalidade das mitocôndrias e na preservação da capacidade fertilizante no teste de penetração in vitro. Assim sendo, o azeite de oliva pode representar uma alternativa para ajudar na criopreservação do sêmen suíno.

\section{Palavras chave}

Antioxidantes, funcionalidade da mitocôndria, teste de penetração in vitro.

\section{Introduction}

The frozen boar semen does not present results as efficient as those of cooled semen, due to the high sensitivity of the sperm to damages during cryopreservation and thaw ${ }^{1}$. Thus, $99 \%$ of the total dose is preserved by cooling, method that ensures a period of storage for up to seven days ${ }^{1}$. However, only the cryopreservation technology enables the prolonged storage of semen for international exchange of genetic material and generation of gene banks ${ }^{2}$. In this context, it is justified to research new strategies for decrease the sperm post-thaw damages for the use of cryopreservation on routine of farms for breeding intensification ${ }^{3}$.

The process of freezing and thawing, provide an increase in generation of reactive oxygen species (ROS) and consequently the oxidative stress ${ }^{4}$. The ROS are involved in important processes of sperm physiology, such as hyperactivation, capacitation, acrosome reaction and events of binding to the zona pellucida ${ }^{5,7}$. However, the ROS excess causes oxidative stress which generates detrimental effects on sperm such as lipid peroxidation ${ }^{8}$, DNA damage ${ }^{9}$, reduction of the capacity for fusion with the oocyte ${ }^{10}$ and reduction of the motility and viability of sperm $^{8}$.
The boar semen is particularly sensitive to oxidative stress due to high content of polyunsaturated fatty acids (PUFAs) in phospholipids of membrane and the low level in proportion cholesterol: phospholipid membrane ${ }^{11}$, besides the low antioxidant activity in seminal plasma that can facilitate oxidative damage also in vivo ${ }^{12}$.

Thus, research on antioxidants has been intense in recent years. Großfeld et al. $(2008)^{2}$ found that the addition of butylated hydroxytoluene, catalase, reduced glutathione, superoxide dismutase, and vitamin E (analogue Trolox) on extenders for freezing boar semen can improve sperm survival after thawing. However, there are few reports on the effects of natural antioxidants for sperm, despite the growing interest in research on natural substances due to security problems and toxicity of some synthetic antioxidants such as butylated hydroxyanisole (BHA) and propyl gallate $(\mathrm{PG})^{13}$.

In research of natural antioxidants, an attractive alternative is olive oil that is extracted from fruit of the olive tree (Olea europaea) through mechanical processes $^{14}$. Olive oil contains a large amount of natural 
antioxidants which provide oxidative stability during storage $^{15}$. Among the antioxidants present in this oil can mention the tocopherols, sterols, carotenoids and phenolic compounds, being the o-dihydroxy-phenolic a potent antioxidant ${ }^{16}$. It is instigating the fact of this compound have not yet been added to the freezing extender because its antioxidant effect is widely reported in the Mediterranean diet, with protective effects against oxidative stress-related diseases such as cancer and neurodegenerative diseases ${ }^{17,18}$.

The viability of using antioxidants in oils has been demonstrated by Kaeoket et al., (2012) $)^{19}$ that used rice bran oil containing the antioxidant gamma-oryzanol for the boar semen cryopreservation and obtained a significantly higher percentage of progressive motility, viability and acrosomal integrity on the supplemented groups compared to control (lactose-yolk).

Thus, the addition of olive oil to freezing extender could neutralize the production of ROS to contain a mixture of antioxidants. The objective of this study was to evaluate the antioxidant activity of olive oil as an additive to the extender for cryopreservation of boar semen.

\section{Materials and methods}

The animals used were boars of Large White and Landrace breed, sexually mature and healthy, housed in a commercial farm in Estrela/RS (longitude 51 $57^{\prime} 59$ "and latitude $\left.29^{\circ} 30^{\prime} 07^{\prime \prime}\right)$. A total of 21 ejaculated from 18 different males are used. The collection occurred by the gloved hand technique and the semen was deposited on tubes with a filter to separate the gelatinous fraction at $38{ }^{\circ} \mathrm{C}^{21}$. Immediately after collection, the semen was diluted at $38{ }^{\circ} \mathrm{C}, 1: 1(\mathrm{v} / \mathrm{v})$ in the Beltsville Thawing Solution extender (BTS). After dilution, the semen was placed at $17{ }^{\circ} \mathrm{C}$ and sent to Pelotas / Rio Grande do Sul not exceeding $4 \mathrm{~h}$ between collection and processing. Cryopreservation occurred in the Veterinary School of the Federal University of Pelotas / Rio Grande do Sul. Only samples that had at least $70 \%$ motility in optical microscopy ${ }^{22,23}$ upon arrival in the laboratory were used for cryopreservation.

For freezing sperm a volume of $15 \mathrm{ml}$ of diluted semen in BTS was centrifuged for 10 minutes at $800 g$. The supernatant was discarded and the pellet resuspended with $400 \mu \mathrm{L}$ cooling extender (CE, lactose-yolk) with osmolarity of $355 \mathrm{mOsm}$ and $\mathrm{pH}$ of 7.2 , containing $80 \%$ (v/ v) lactose solution at 11 and $20 \%(\mathrm{v} / \mathrm{v})$ egg yolk. After, the $400 \mu \mathrm{L}$ above mentioned (CE plus cooling extender) were distributed and diluted on the following treatments: Cont (CE only); A0,25 (0.25\% olive oil in $\mathrm{CE})$; A0,50 ( $0.5 \%$ olive oil in CE); A0,75 (0.75\% olive oil in $\mathrm{CE})$ and $\mathrm{A} 1,0$ (1.0\% olive oil in $\mathrm{CE})$.

The olive oil used was the variety "Koroneiki" got picked fruit grown olive trees in the city of Bage/RS mechanically cold processed with extractor Spremoliva (Oliomio/ Italy). The determination of antioxidant compounds was performed by spectrophotometry to determine the phenols and carotenoids and liquid chromatography (HPLC) for total tocopherols, these compounds being shown in Table 1. After dilution in treatments semen was cooled in the refrigerator at $5{ }^{\circ} \mathrm{C}$ and remained at that temperature for 90 minutes.

Table 1. Antioxidant compounds present in olive oil variety "Koroneiki" values expressed as mean and standard deviation.

\begin{tabular}{ccccc}
\hline Total Phenols & Total Carotenoids & \multicolumn{3}{c}{ Tocopherols } \\
\hline$(\mathrm{mg} / \mathrm{kg})$ & $(\mathrm{mg} / \mathrm{kg})$ & Alfa- $\alpha$ & Gama $\beta+\gamma$ & Delta- $\delta$ \\
$112.2 \pm 1.3$ & $6.53 \pm 0.05$ & $39.5 \pm 1.6$ & $1.1 \pm 0.01$ & - \\
\hline
\end{tabular}

After this period at $5{ }^{\circ} \mathrm{C}$, semen was diluted in freezing extender (FE) with $83.5 \%$ of CE; $1.5 \%$ of Orvus Ex Paste and $15 \%$ of cryoprotectant $\mathrm{N}$, N-dimethylacetamide (DMA) $\left(\mathrm{C}_{4} \mathrm{H}_{9} \mathrm{NO}\right)(\mathrm{v} / \mathrm{v})$. The addition of FE occurred in 1:2 ratio, i.e. for each $2 \mathrm{ml}$ of $\mathrm{CE}$ was adding $1 \mathrm{~mL}$ of $\mathrm{FE}$ to present a DMA final concentration of $5 \%{ }^{24}$. At the end of this dilution in DC, each treatment had a concentration of $5 \times 10^{7}$ sperm $/ \mathrm{mL}$ per $0.25 \mathrm{~mL}$ straws. After filling, the straws were stored at $5 \mathrm{~cm}$ from nitrogen vapor for 10 minutes. Then these straws were immersed and stored in liquid nitrogen at $-196{ }^{\circ} \mathrm{C}$.
After 7 days of storage in liquid nitrogen, the straws were thawed in a water bath at $37{ }^{\circ} \mathrm{C}$ for 30 seconds and its contents stored in conical tubes containing 2.5 $\mathrm{mL}$ of BTS, preheated to $37^{\circ} \mathrm{C}^{25,26}$. The thawed semen was incubated for 10 minutes and analysis of sperm performed.

Motility was assessed by Bearden \& Fuquay (1997) and CBRA, (1998) ${ }^{22,23}$ by viewing through optical microscopy in 200x magnification, an aliquot of $20 \mu \mathrm{L}$ in slide under coverslip, both previously heated to $37^{\circ} \mathrm{C}$. 
For evaluation of the DNA integrity in a $20 \mu \mathrm{L}$ semen aliquot added $10 \mu \mathrm{L}$ of buffer TNE $(0.01 \mathrm{M}$ Tris-HCl, 0.15 $\mathrm{M} \mathrm{NaCl}, 0.001 \mathrm{M}$ EDTA, $\mathrm{pH}$ 7.2) after 30 seconds, $20 \mu \mathrm{L}$ of detergent Triton $1 \mathrm{X}$ and after another 30 seconds added $10 \mu \mathrm{L}$ of acridine orange $(2 \mathrm{mg} / \mathrm{mL}$ in deionized $\mathrm{H}_{2} \mathrm{O}$ ). The evaluation of DNA integrity occurred 5 minutes after addition of reagents to the semen in epifluorescence microscope, by counting 100 cells, considering cells with damaged DNA those presenting red or orange fluorescence and integrity those presenting green fluorescence as described by Varela et al. $(2012)^{27}$.

Functionality of mitochondria was assessed using a probe specific, Rhodamine 123 (Rh123) (R8004-5 mg) together with propidium iodide (PI) second modified protocol of Garner et al. $(1997)^{28}$. At a $20 \mu \mathrm{L}$ of semen aliquot was added $30 \mu \mathrm{L}$ of a working solution containing: $960 \mu \mathrm{L}$ of sodium citrate solution (2.94\%), $10 \mu \mathrm{L}$ of formaldehyde $(1.7 \mathrm{~mm}), 10 \mu \mathrm{L}$ of PI $(7.3 \mathrm{~mm})$ and $20 \mu \mathrm{L}$ of Rh123 $(0.2 \mathrm{mM})$. A total of 100 cells were evaluated at $400 \mathrm{x}$ magnification on epifluorescence microscope. Cells that had intermediate piece with an intense green fluorescence were classified like intact mitochondria (functionally active), whereas cells with low green fluorescence (matte) in the intermediate piece were deemed functional.

To evaluate the rate penetration of oocyte and number of spermatozoa per oocyte (on in vitro penetration test), ovaries of prepubertal gilts were collected at a slaughterhouse and transported to the laboratory within $60 \mathrm{~min}$, in saline solution $(0.90 \%)$ containing gentamicin $(40 \mathrm{mg} / \mathrm{ml})$ at $30{ }^{\circ} \mathrm{C}$. In the laboratory, follicles (3-6 $\mathrm{mm})$ are were aspirated with the aid of a vacuum pump and oocytes with intact zona pellucida were frozen $\left(-18^{\circ} \mathrm{C}\right)$ for later use. After thawing, the cumulus cells were mechanically removed with the aid of a micropipette of $200 \mu \mathrm{L}$ and processing of oocytes was performed as described by Macedo et al. (2006) and Macedo et al. $(2010)^{29,30}$. The in vitro rate penetration test occurred at 30 oocytes per sample according Maleszewski et al. $(1995)^{31}$ with modifications: the fertilization medium was the modified Tris (mTBM) comprising: $113.1 \mathrm{mM}$ $\mathrm{NaCl}, 3.0 \mathrm{mM} \mathrm{KCl}, 10.0 \mathrm{mM} \mathrm{CaCl}, 20.0 \mathrm{mM}$ Tris, 11.0 $\mathrm{mM}$ glucose, $5.0 \mathrm{mM}$ sodium pyruvate, $0.4 \%$ of bovine serum albumin and $5 \mathrm{mM}$ caffeine. The co-incubation of gametes was carried out in microcentrifuge tubes with 1 $\mathrm{mL}$ of $\mathrm{mTBM}$ in a water bath at $37^{\circ} \mathrm{C}$ for 2 hours. The sperm concentration of $4.10^{6} / \mathrm{mL}$. After co-incubation, oocytes were recovered, washed, stained with Hoechst $33342(10 \mathrm{mg} / \mathrm{ml})$ and evaluated in epifluorescence microscope at 400x. Finally, oocytes were considered penetrated when their zona pellucida contained at least one sperm in perivitelline or cytoplasm space ${ }^{29,30}$.
For each male, the number of oocytes penetrated were counted and the rate of in vitro penetration calculated by the division of the number of oocytes penetrated on total oocytes (not penetrated and penetrated).

The variables of motility, DNA integrity, mitochondrial functionality, number of spermatozoa per oocyte and rate penetration were subjected to the Shapiro-Wilk normality test, which indicated the absence of normality. Thus, the averages for these variables were compared by Kruskal-Wallis test, and all statistical analyzes the software Statistix $9.0(2008)^{32}$. The confidence interval for all evaluations was $5 \%$.

\section{Results}

There was no statistical difference between the different treatments with olive oil and control (lactose-yolk only) for motility, DNA integrity and functionality of mitochondria (Table 2).

Table 2. Thawed boar semen: Mean and standard error of the mean for motility (MOT), functionality of mitochondria (FM) and DNA integrity (IDNA).

\begin{tabular}{cccc}
\hline Treatment & MOT (\%) & IDNA (\%) & FM (\%) \\
\hline Cont & $21.1 \pm 3.1$ & $87.7 \pm 5.4$ & $47.7 \pm 5.1$ \\
A025 & $14.0 \pm 2.1$ & $89.9 \pm 5.8$ & $50.5 \pm 5.4$ \\
A050 & $14.7 \pm 2.2$ & $91.7 \pm 4.7$ & $40.7 \pm 6.2$ \\
A075 & $13.5 \pm 2.0$ & $82.6 \pm 7.2$ & $40.8 \pm 5.8$ \\
A10 & $14.0 \pm 2.3$ & $88.4 \pm 4.9$ & $40.2 \pm 4.8$ \\
\hline
\end{tabular}

Cont (control, lactose-yolk); A025 (lactose-yolk more $0.25 \%$ olive oil); A050 (lactose-yolk more $0.50 \%$ olive oil); A075 (lactose-yolk more $0.75 \%$ olive oil); A10 (lactose-yolk more $1.0 \%$ olive oil), means were compared by Kruskal-Wallis.

There was no statistical difference between treatments with olive oil and control (lactose-yolk only) for the number of spermatozoa per oocyte and penetration rate (Table 3).

The variables analyzed showed no statistical difference compared to control. However, treatments with olive oil showed a tendency to protect against damage from freezing compared to control (lactose-yolk) (Table 2 and Table 3). 
Table 3. Thawed boar semen: Mean and Standard Error for the average sperm number per oocyte $(\mathrm{SN})$ and penetration rate $(\mathrm{PR})$.

\begin{tabular}{ccc}
\hline Treatment & $\boldsymbol{S N}$ & $\boldsymbol{P R}$ \\
\hline Cont & $2.6 \pm 0.4$ & $76.9 \pm 5.2$ \\
A025 & $4.4 \pm 0.1$ & $83.9 \pm 4.6$ \\
A050 & $2.6 \pm 0.3$ & $73.2 \pm 5.2$ \\
A075 & $3.2 \pm 0.5$ & $74.6 \pm 3.8$ \\
A10 & $2.9 \pm 0.5$ & $73.1 \pm 4.1$ \\
\hline
\end{tabular}

Cont (control, lactose-yolk); A025 (lactose-yolk more $0.25 \%$ olive oil); A050 (lactose-yolk more 0.50\% olive oil); A075 (lactose-yolk more $0.75 \%$ olive oil); A10 (lactose-yolk more $1.0 \%$ olive oil), means were compared by Kruskal-Wallis.

\section{Discussion}

This is the first report of the use of olive oil for freezing boar semen and demonstrates an interesting field of research, especially due to be a natural antioxidant with superior safety and potential toxicity lower than synthetic antioxidants ${ }^{13}$.

Among the trends of protection (Tab. 2 and Tab. 3) has verified that sperm motility showed levels below 20\% in all treatments and $21 \%$ for the control, similar to the averages reported by Jiang et al., (2007) $)^{33}$; Bianchi et al., (2008) ${ }^{24}$; Gutiérrez-Pérez et al., (2009) ${ }^{34}$; Zeng et al., (2014) ${ }^{35}$. The reduced motility in treatment may be justified due to the viscosity of olive oil ${ }^{36}$, does not represent a loss for this variable. Moreover, a higher viscosity may reduce sperm metabolic demand prolonging the viability of gametes, as demonstrated by Nagy et al. (2002) $)^{37}$ and López-Gatius et al. $(2005)^{38}$ for rabbit spermatozoa.

The trends of semen protection are shown in other results helps to prove the fact that reduced motility is not due to a toxic effect but to a higher viscosity of olive oil. Thus, the protection trend against cryopreservation damages is remarkable to the variables of DNA integrity and functionality of mitochondria, being the highest averages for DNA integrity at concentrations of $0.25 \%$ and $0.50 \%$ olive oil and for mitochondria functionality the highest average at concentrations $0.25 \%$ olive oil $(p>0.05)$ exceeding the control for both. In this context, this trend of protection is very promising, since mitochondrial function is critical for ATP production, which sustains the flagellar beats for the motility ${ }^{39}$, and DNA integrity is essential for the correct embryonic development ${ }^{40}$ and birth of healthy offspring.

The $0.25 \%$ concentration had already demonstrated beneficial effects for the variables of DNA integrity and function of mitochondria, also demonstrated trend of protection by penetration testing. Thus, olive oil generated the greatest number of sperm per oocyte as well as the higher rate of penetration. Penetration testing conducted by co-incubation of gametes is more predictive of fertility compared to tests that evaluate the sperm alone ${ }^{41,42}$, in addition to this test have shown sensitivity in detecting fertilizing ability of boar sperm ${ }^{29}$.

Semen is a biological sample with large variation, since hardly showed normal distribution in various evaluations of seminal quality ${ }^{43,44,45,46}$ and that increased sampling contributes to decrease variability ${ }^{47}$. Thus, it is believed that increasing the sampling demonstrate the differences statistically between treatments containing olive oil and control because many experiments assessing sperm quality with larger samples obtained superior results in the treated groups ${ }^{24,33,48}$.

The results in this paper are promising due to trends protection has presented considering the great sensitivity of boar semen to freezing. Thus, is there the perspective to evaluate other varieties of olive oil, beyond the "Koroneiki", because according Minioti and Georgiou $(2008)^{15}$ the composition of the most potent antioxidants (phenols), is variable between different olive oils.

\section{Conclusion}

Olive oil at a concentration of $0.25 \%$ was found for the protection of boar sperm against damage from freezing.

\section{Acknowledgments}

Thank Embrapa Temperate Climate for the supply of olive oil, and thank financial support for this study was from Brazilian Conselho Nacional de Desenvolvimento Científico e Tecnológico (CNPq no 459609/2014-9) and Universidade Federal do Rio Grande, Rio Grande, RS, Brazil. C.D. Corcini is a research fellow from the Brazilian Conselho Nacional de Desenvolvimento Científico e Tecnológico (CNPq nº 306356/2014-7).

\section{References}

1. Johnson LA, Weitze KF, Fiser P, Maxwell WMC. Storage of boar semen. An Reprod Sci 2000; 62 (1-3): $143-172$. 
2. Großfeld R, Sieg B, Struckmann C, Frenzel A, Maxwell WMC, Rath D. New aspects of boar semen freezing strategies.Theriogenology 2008; 70(8): 1225-1233.

3. Bailey JL, Lessard C, Jacques J, Brèque C, Dobrinski I, Zeng W. et al. Cryopreservation of boar semen and its future importance to the industry. Theriogenology 2008; 70(): 1251-1259.

4. Chatterjee S, Gagnon C. Production of reactive oxygen species by spermatozoa undergoing cooling, freezing and thawing. Mol Reprod Develop 2001; 59(4): 451-458.

5. Kodama H, Kuribayashi Y, Gagnon C. Effect of sperm lipid peroxidation on fertilization. J Androl 1996; 17(2): 151-157.

6. Belén Herrero M, De Lamirande E, Gagnon C. Nitric oxide is a signaling molecule in spermatozoa. Cur Pharm Design 2003; 9(5): 419-425.

7. Bucak MN, Atessahin A, Varish Ö, Yuce A, Tekin N, Akçay A. The influence of trehalose, taurine, cysteamine and hyaluronan on ram semen: microscopic and oxidative stress parameters after freeze-thawing process. Theriogenology 2007; 67(5): 1060-1067.

8. Baumber J, Ball BA, Linfor JJ, Meyers AS. Reactive oxygen species and cryopreservation promote DNA fragmentation in equine spermatozoa. J Androl 2003; 24(4): 621-628.

9. Griveau JF, Le Lannou D. Reactive oxygen species and human spermatozoa: physiology and pathology. In J Androl 1997; 20(2): 61-69.

10. Johnson LA, Gerrits RJ, Young EP. The fatty acid composition of porcine spermatozoa phospholipids. Biol Reprod 1969; 1: 330-334.

11. Brezezinska-Slebodzinska E, Slebodzinski AB, Pietras B, Wieczorek G. Antioxidant effect of vitamin $\mathrm{E}$ and glutathione on lipid peroxidation in boar semen plasma. Biol Trace Elem Res 1995; 47(1-3): 69-74.

12. Malo C, Gil L, Cano R, Martínez F, Galé I. Antioxidant effect of rosemary (Rosmarinus officinalis) on boar epididymal spermatozoa during cryopreservation. Theriogenology 2011; 75(9): 1735-1741.

13. Baccouri O, Bendini A, Cerretani L, Guerfel M, Baccouri B, Lercker $\mathrm{G}$ et al. Comparative study on volatile compounds from Tunisian and Sicilian monovarietal virgin olive oils. Food Chem 2008; 111(2): 322-328.
14. Minioti KS, Georgiou CA. High throughput flow injection bioluminometric method for olive oil antioxidant capacity. Food Chem 2008; 109(2): 455-461.

15. Boskou D, Blekas G, Tsimidou M. Phenolic compounds in olive oil and olives. Cur Topics Nut Res 2005; 3: 125-136.

16. López-Miranda J, Pérez-Jiménez F, Ros E, et al. Olive oil and health: Summary of the II international conference on olive oil and health consensus report, Jaén and Córdoba (Spain) 2008. Nut, Metabol Card Dis 2010; 20(4): 284-294.

17. Mascitelli L, Pezzetta F, Goldsteinc MR. Is the Beneficial Antioxidant Effect of Olive Oil Mediated by Interaction of its Phenolic Constituents and Iron? Arch Med Res 2010; 41(4): 295-296.

18. Kaeoket K, Donto S, Nualnoy P, Noiphinit J, Chanapiwat P. Effect of gamma-oryzanol enriched rice bran oil on quality of cryopreserved boar semen. J Vet Med Sci 2012; 74(9): 1149-1153.

19. Hancock JL, Hovell GJR, (1959). The collection of boar semen. Vet Rec 71, 664-665.

20. Bearden HJ, Fuquay JW. Semen evaluation. In: Bearden HJ, Fuquay JW. Applied Animal Reproduction. 4nd ed. New Jersey: Prentice Hall; 1997. P. 159-170.

21. CBRA. (1998). Manual para exame andrológico e avaliação de sêmen animal. Colégio Brasileiro de Reprodução Animal. $2^{\mathrm{a}}$ Ed. Belo Horizonte: CBRA, 49.

22. Bianchi I, Calderam K, Maschio EF, Madeira EM, Ulguim RR, Corcini CD et al. Evaluation of amides and centrifugation temperature in boar semen cryopreservation. Theriogenology 2008; 69(5): 632-638.

23. Maxwell WMC, Johnson LA. Membrane status of boar spermatozoa after cooling or cryopreservation. Theriogenology 1997; 48(2): 209-219.

24. Peña FJ, Johannisson A, Wallgren M, RodríguezMartinez H. Assessment of fresh and frozen-thawed boar semen using an Annexin-V assay: a new method of evaluating sperm membrane integrity. Theriogenology 2003; 60(4): 677-689.

25. Varela Jr AS, Corcini CD, Gheller SMM, Jardim $\mathrm{RD}$, Lucia Jr T, Streit Jr, DP et al. Use of amides as cryoprotectants in extenders for frozen sperm of tambaqui, Colossoma macropomum. Theriogenology 2012; 78(2): 244-251. 
26. Garner DL, Thomas CA, Joerg HW. Fluorometric assessments of mithochondrial function and viability in cryopreserved bovine spermatozoa. Biol Reprod 1997; 57(6): 1401-1406.

27. Macedo Jr MC, Deschamps JC, Lucia Jr T, Bordignon $\mathrm{J}$, Serret CG, Rambo $\mathrm{G}$ et al. In vitro penetration of fresh and vitrified swine oocytes by homologous spermatozoa using different incubation systems. Na Reprod Sci 2006; 92(3-4): 334-348.

28. Macedo Jr MC, Lucia Jr T, Rambo G, Ferreira Filho $\mathrm{E}$, Rosa A, Fabiane C. et al. In vitro penetration of swine oocytes by homologous spermatozoa: distinct systems for gamete's coincubation and oocyte's cryopreservation. An Reprod Sci 2010; 117(3-4): 295-301.

29. Maleszewski M, Kline D, Yanagimachi R. Activation of hamster zone-free oocytes by homologous and heterologous spermatozoa. J Reprod Fert 1995; 105: 99-107.

30. Statistix ${ }^{\circledR} 9$ 9. Analytical Software. User's manual. 396 p. Tallahassee. FL. 2008.

31. Jiang Z-I, Li Q-W, Hu J-H, Li W-Y, Zhao H-W, Zhang $\mathrm{S}$-S. Improvement of the quality of boar cryopreservation semen by upplementing with low density lipoprotein in diluents. Cryobiology 2007; 54(3): 301-304.

32. Gutiérrez-Pérez O, Juárez-Mosqueda ML, Carvajal SU, Ortega MET. Boar spermatozoa cryopreservation in low glycerol/trehalose enriched freezing media improves cellular integrity. Cryobiology 2009; 58(3): 287-292.

33. Zeng C, Peng W, Ding L, He L, Zhang Y, Fang D, Tang K. A preliminary study on epigenetic changes during boar spermatozoa cryopreservation, Cryobiology. 2014; 69(1): 119-127.

34. Schaschke CJ, Allio S, Holmberg E.Viscosity measurement of vegetable oil at high pressure. Food Bioprod Proces 2006; 84(3): 173-178.

35. Nagy S, Sinkovics G, Kovács A. Viability and acrosome integrity of rabbit spermatozoa processed in a gelatin-supplemented extender. An Reprod Sci 2002; 70(3-4): 283-286.

36. López-Gatius F, Sances G, Sancho M, Yániz J, Santolaria P, Gutiérrez R, Núñez M, Núñez J, Soler C. Effect of solid storage at $15{ }^{\circ} \mathrm{C}$ on the subsequent motility and fertility of rabbit semen. Theriogenology 2005; 64(2): 252-260.
37. Connell MO, McClure N, Lewis SEM.The effects of cryopreservation on sperm morphology, motility and mitochondrial function. H Reprod 2002; 17(3): 704-709.

38. Haines GA, Hendry JH, Daniel P, Morris ID. Increased levels of comet-detected spermatozoa DNA damage following in vivo isotopic - or X-irradiation of spermatogonia. Mutation Res 2001; 495(1-2): 21-32.

39. Rodriguez-Martinez H. Laboratory semen assessment and prediction of fertility: still utopia? Reprod Dom An 2003; 38(4): 312-318.

40. Gadea J, García-Vázquez FA, Matías C, Gardón JC, Cánovas S, Gumbao, D. Cooling and freezing of boar spermatozoa: Supplementation of the freezing media with reduced glutathione preserves sperm function. $\mathrm{J}$ Androl 2005; 26(3): 396-404.

41. Pérez LJ, Valcárcel A, de las Heras MA, Moses $\mathrm{D}$, Baldassarre H. Evidence that frozen/thawed ram spermatozoa show accelerated capacitation in vitro as assessed by chlortetracycline assay. Theriogenology 1996; 46(1):131-140.

42. Hernández M, Roca J, Gil MA, Vázquez JM, Martínez EA. Adjustments on the cryopreservation conditions reduce the incidence of boar ejaculates with poor sperm freezability. Theriogenology 2007; 67(9): 1436-1445.

43. Satorre MM, Breininger E, Beconi MT. Cryopreservation with $\alpha$-tocopherol and Sephadex filtration improved the quality of boar sperm. Theriogenology 2012; 78(7): 1548-1556.

44. Silva ECB, Cajueiro JFP, Silva SV, Vidal AH, Soares PC, Guerra MMP. In vitro evaluation of ram sperm frozen with glycerol, ethylene glycol or acetamide An Reprod Sci 2012; 132(3-4): 155- 158.

45. Likhachev VP, da Cruz MTF, Mesa J. Quantas Medidas são necessárias para o conhecimento de uma grandeza física? Rev Bras Ens Física 2000; 22(4): 456462.

46. Fraser L, Dziekonska A, Strzezek R, Strzezek J. Dialysis of boar semen prior to freezing-thawing: Its effects on post-thaw sperm characteristics. Theriogenology 2007; 67(5): 994-1003. 